Original Artikel

Spizaetus: Jurnal Biologi dan Pendidikan Biologi

Volume 2 Nomor 3, Oktober 2021

PISSN : 2716-151X

eISSN: 2722-869X

\title{
Efektivitas Model Pembelajaran Kooperatif Tipe Class-Wide Peer Tutoring Dilihat Dari Aktivitas dan Hasil Belajar Kognitif Pada Materi Klasifikasi Makhluk Hidup Kelas X di SMA Swasta Katolik St. John Paul II Maumere
}

\section{The Effectiveness of Cooperative Learning in Class-Wide Peer Tutoring Tipe as Viewed from Learning Activities and Kognitif Learning outcome on the Living Things Classification Material at Grade X of SMAK St. John Paul II Maumere}

\author{
Monalita Krisyanti Bang'1, Yohanes Boli Tematan², Yohanes Nong Bunga ${ }^{3 *}$ \\ ${ }^{1,2,3}$ Program Studi Pendidikan Biologi, Fakultas Keguruan dan Ilmu Pendidikan, Universitas Nusa Nipa, \\ Maumere, 86111, Indonesia \\ *email: Uma.Sandy910@gmail.com
}

\begin{abstract}
ABSTRAK
Penelitian ini bertujuan untuk mengetahui efektivitas model pembelajaran kooperatif tipe Class-Wide Peer Tutoring dilihat dari aktivitas dan hasil belajar kognitif pada materi klasifikasi makhluk hidup kelas X SMAS Katolik St. John Paul II Maumere. Penelitian ini menggunakan metode Quasi Eksperiment dengan desain penelitian Nonequivalent Control Group Design. Sampel ditentukan menggunakan teknik Purposive Sampling. Sampel dalam penelitian ini adalah siswa kelas XIPA ${ }^{2}$ sebagai kelas eksperimen dan X IPA ${ }^{1}$ sebagai kelas kontrol. Instrument yang digunakan adalah lembar observasi untuk mengukur aktifitas dan tes hasil belajar siswa dalam bentuk soal pilihan ganda. Instrument ini telah dilakukan pengujian validitas, reliabilitas, taraf kesukaran dan daya pembeda soal. Hasil analisis data observasi aktifitas belajar siswa menunjukan bahwa rata-rata pada kelas eksperimen sebesar 3,45 sedangkan kelas kontrol sebesar 2,26. Hasil uji t menunjukan bahwa 0,000 < 0,05. Hal ini menunjukan bahwa penggunaan model pembelajaran kooperatif tipe Class-Peer Tutoring efektif dalam meningkatkan aktifitas dan hasil belajar siswa kelas X SMAS Katolik St. John Paul II Maumer
\end{abstract}

Kata Kunci: Aktifitas; Hasil Belajar; Model Pembelajaran Class-Wide Peer Tutoring 


\section{PENDAHULUAN}

Pendidikan memiliki peran dan posisi penting dalam pelaksanaan pembangunan. Pembangunan di bidang pendidikan bertujuan untuk mewujudkan manusia yang cakap, terampil, dan berilmu sebagai bekal hidup di tengah pesatnya perkembangan IlmuPengetahuan dan Teknologi (IPTEK). Undang-Undang Republik Indonesia No. 20 Tahun 2003 Bab 1 Pasal 1 menyatakan bahwa pendidikan adalah usaha sadardan terencana untuk mewujudkan suasana belajar dan proses pembelajaran agar peserta didik secara aktif mengembangkan potensi dirinya untuk memiliki kekuatan spiritual keagamaan, pengendalian diri, kepribadian, kecerdasan, akhlak mulia, serta ketrampilan yang diperlukan dirinya, masyarakat, bangsa dan Negara (Latif, 2007).

Kurikulum 2013 menjelaskan proses pembelajaran merupakan salah satu elemen dari standar proses yang mengalami perubahan guna pencapaian keberhasilan pembelajaran dan pembentukan kompetensi siswa. Peraturan Menteri Pendidikan dan Kebudayaan Republik Indonesia No. 22 Tahun 2016 menjelaskan bahwa proses pembelajaran pada suatu pendidikan diselenggarakan dengan cara interaktif, inspiratif, menyenangkan, menantang, memotivasi peserta didik untuk berpartisipasi aktif, serta memberikan ruang yang cukup bagi prakarsa, kreativitas, dan kemandirian sesuai dengan bakat, minat, dan perkembangan fisik serta psikis peserta didik. Untuk itu setiap satuan pendidikan harus melakukan perencanaan pembelajaran, pelaksanaan proses pembelajaran serta penilaian proses pembelajaran untuk meningkatkan efisiensi dan efektivitas ketercapaian kompetisi lulusan. Proses pembelajaran yang sesuai dengan Permendikbud No 22 Tahun 2016 belum sepenuhnya diterapkan di SMAS Katolik St. John Paul II Maumere.

Hasil observasi peneliti di SMAS Katolik St. John Paul II Maumere, diketahui pelajaran di kelas belum memiliki kualitas yang optimal. Guru melaksanakan pembelajaran dengan metode ceramah, tanya jawab, dan diskusi kelompok. Metode pembelajaran ini membuat siswa kurang proaktif dalam proses pembelajaran. Permasalahan tersebut merupakan suatu hal yang kompleks yang membutuhkan penyelesaian. Penyebab yang paling menonjol adalah siswa kurang dilibatkan dalam pembelajaran, sehingga mengakibatkan aktivitas, respon baik secara intelektual maupun emosional, dan motivasi siswa dalam mengikuti pelajaran di kelas masih rendah. Kondisi ini diduga menyebabkan hasil belajar kognitif belum maksimal sesuai yang diharapkan dalam Kriteria Ketuntasan Maksimal (KKM) pada mata pelajaran biologi yaitu 75 , sedangkan nilai rata-rata siswa adalah 65 .

Pembelajaran biologi bertujuan untuk memperoleh konsep dan teori, oleh karena itu siswa perlu dilatih untuk mengamati, mengelompokkan, meneliti, dan kemudian mengkomunikasikan. Guru harus dapat menggunakan metode yang tepat agar siswa mendapatkan hasil belajar yang memuaskan, salah satunya adalah penggunaan metode pembelajaran yang bervariasi. Selain merencanakan model pembelajaran yang 
bervariasi, seorang guru harus dapat mengembangkan kreasi dan keterampilannya sesuai dengan kondisi sekolah dan lingkungan siswa. Keberhasilan proses pembelajaran biologi, sangat di pengaruhi oleh bagaimana peran guru dan siswa.

Guru mempunyai peran penting dalam menciptakan lingkungan belajar yang menarik dan baik bagi siswa dalam berlangsungnya proses pembelajaran. Untuk melaksanakan proses belajar mengajar, apabila tidak didukung oleh sumber, media, alat peraga dan model pembelajaran yang sesuai dengan materi pembelajaran yang diajarkan tentu hasilnya tidak akan memuaskan. Penggunaan model pembelajaran yang melibatkan keaktifan siswa juga masih jarang digunakan, sehingga siswa merasa jenuh dan kurang berminat untuk belajar. Hal ini menarik perhatian peneliti untuk memperbaiki kekurangan dalam proses pembelajaran.

Berdasarkan beberapa uraian di atas, penulis tertarik untuk menerapkan model pembelajaran Class-Wide Peer Tutoring (CWPT). CWPT atau disebut juga pengajaran berpasangan seluruh kelas, merupakan salah satu model pembelajaran kooperatif yang melibatkan dua orang siswa untuk saling menyampaikan materi. Model pembelajaran ini mengharuskan siswa berperan sebagai tutor dan tutee secara bergantian selama proses tutoring, sehingga tutor maupun tutte menunjukan kemampuan penguasaan materi. Model pembelajaran Class-Wide Peer Tutoring juga mampu memperbaiki sikap siswa dalam proses pembelajaran karena pada sesi Tutoring siswa dituntut untuk aktif baik berlaku sebagai tutor maupun tutee secara bergantian Hidayah, $d k k$. (2012).

Aktivitas merupakan hal yang penting di dalam proses belajar mengajar. Sudjana (2010) mengungkapkan bahwa aktivitas belajar siswa mencakup dua aspek yang tidak terpisahkan yakni aktivitas mental (emosional-intelektual-sosial) dan aktivitas motorik (gerak fisik). Aktivitas inilah yang memiliki hubungan erat dengan hasil belajar. Ketika seluruh aspek aktivitas terlaksana maka tidak hanya pengalaman belajar yang tinggi yang didapatkan tetapi juga hasil belajar akan maksimal.

Jenkins dan Unwin mengatakan bahwa hasil belajar adalah pernyataan yang menunjukkan tentang apa yang mungkin dikerjakan siswa sebagai hasil dari kegiatan belajarnya. Hasil belajar dapat diketahui setelah dengan melakukan penilaian atau evaluasi yang dilakukan oleh guru sebelum pengajaran dimulai (pretest), pada saat berlangsungnya proses belajar mengajar untuk mengetahui pemahaman siswa, atau dilakukan pada akhir pengajaran (posttest). Agar aspek aktivitas dan hasil belajar dapat tercapai dengan maksimal, maka perlu adanya kesadaran dalam proses pembelajaran dalam cara mengajar dan metode yang digunakan dalam proses belajar mengajar. Mengajar pada dasarnya merupakan kegiatan akademik yang berupa interaksi komunikasi antara guru dan siswa dalam upaya memberikan stimulus, bimbingan, pengarahan, dan dorongan kepada siswa agar proses belajar mengajar dapat berjalan dengan baik sesuai dengan yang diharapkan.

Pembelajaran Class-Wide Peer Tutoring ini siswa diajarkan untuk mandiri, 
dewasa dan punya rasa setia kawan yang tinggi, siswa lebih mudah dan leluasa dalam menyampaikan masalah yang dihadapi, membuat siswa yang kurang aktif menjadi aktif serta membantu siswa yang kurang mampu atau kurang cepat menerima pelajaran dari gurunya. Berpedoman pada fenomena permasalahan yang dipaparkan diatas, maka peneliti tertarik untuk melakukan penelitian dengan judul

\section{METODE}

Jenis penelitian ini adalah Quasi Experiment Design. Pada penelitian ini, terdapat dua kelas yang akan digunakan yaitu kelas kontrol dan kelas ekperimen. Rancangan penelitian yang digunakan adalah Nonequivalent Control Group Design. Penelitian dilaksanakan pada tanggal 26 Agustus - 8 September 2020 di SMAS Katolik St. John Paul II Maumere.

Penelitian menggunakan seluruh siswa kelas X IPA di SMAS Katolik St. John Paul II Maumere sebagai ppulasi. Jumlah kelas X IPA di SMAS Katolik St. John Paul II Maumere terdapat dua kelas yang bagi atas kelas $\mathrm{X} \mathrm{IPA}^{1}$ dan $\mathrm{X} \mathrm{IPA}^{2}$. Penelitian ini
"Efektivitas Model Pembelajaran Kooperatif Tipe Class-Wide Peer Tutoring Dilihat Dari Aktivitas Dan Hasil Belajar Kognitif Pada Materi Klasifikasi Makhluk Hidup Kelas X Di SMA Swasta Katolik St. John Paul II Maumere". menggunakan dua kelas yang dijadikan sebagai sampel yaitu kelas X IPA ${ }^{1}$ dan kelas $\mathrm{X} \mathrm{IPA}^{2}$. Kelas X IPA ${ }^{2}$ dipilih sebagai kelas eksperimen dan $\mathrm{X} \quad \mathrm{IPA}^{1}$ sebagai kelas kontrol.

Penelitian terdiri dari 3 tahapan, yaitu pra-penelitian, perencanaan dan tahap pelaksanaan penelitian. Instrumen penelitian yang digunakan adalah tes pilihan ganda yang diberikan kepada siswa pada akhir proses pembelajaran. Pada penelitian ini peneliti mengumpulkan data dengan memberikan tes dan pengamatan (observasi).

\section{HASIL DAN PEMBAHASAN}

\section{a. Efektivitas Model Pembelajaran Class- Wide Peer Tutoring (CWPT) dilihat dari Aktivitas Belajar Siswa}

Data hasil aktivitas belajar siswa diperoleh menggunakan lembar observasi dengan jumlah 7 aspek pengamatan dan 19 indikator. Pengukuran aktivitas belajar siswa dilakukan pada kelas eksperimen dan kelas kontrol dengan skala observasinya adalah 1 untuk kriteria kurang baik, 2 untuk kriteria cukup baik, 3 untuk kriteria baik, dan 4 untuk kriteria sangat baik. Berikut merupakan tabel observasi aktivitas siswa pada kelas kontrol dan eksperimen. 
Tabel 1. Hasil Observasi Aktivitas Siswa

\begin{tabular}{ccc}
\hline \multirow{2}{*}{ Pertemuan } & \multicolumn{2}{c}{ Kelas } \\
\cline { 2 - 3 } & Eksperimen & Kontrol \\
\hline Petemuan 1 & 3,35 & 2,55 \\
\hline Pertemuan 2 & 3,55 & 2,75 \\
\hline Rata-rata & 3,45 & 2,65
\end{tabular}

Tabel rata-rata diatas menunjukan bahwa nilai observasi aktivitas kelas eksperimen sebesar 3,45 dengan nilai maksimum 3,55 dan nilai minimum 3,35, sedangkan pada kelas kontrol perolehan nilai rata-rata sebesar 2,26 dengan nilai maksimum 2,75 dan nilai minimu 2,55.

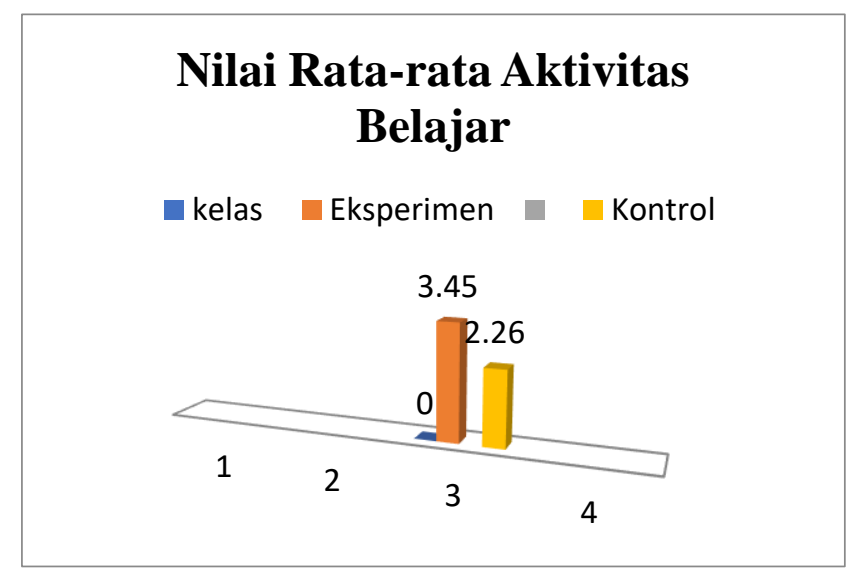

Gambar 1. Nilai Rata-rata Hasil Observasi Aktivitas Belajar

Berdasarkan gambar di atas, perbedaan nilai rata-rata aktivitas belajar siswa yang diperoleh kelas eksperimen dengan menggunakan model class wide peer tutoring (CWPT) sebesar 3,45 sedangkan kelas kontrol yang menggunakan model pembelajaran problem based learning (PBL) sebesar 2,26. Hal ini dikarenakan melalui pembelajaran class-wide peer tutoring siswa dituntut untuk aktif baik berlaku sebagai tutor maupun tutee secara bergantian sehingga mampu memperbaiki sikap siswa dalam proses pembelajaran.

Sani (2015) menyatakan bahwa model class wide peer tutoring merupakan pembelajaran yang dibantu seorang peserta didik yang kompeten untuk mengajar peserta didik lainnya. Pembelajaran menggunakan Class-Wide Peer Tutoring siswa diajarkan untuk mandiri, dewasa dan memiliki rasa setia kawan yang tinggi, siswa lebih mudah dan leluasa dalam menyampaikan masalah yang dihadapi, 
memberi pengaruh kepada siswa yang kurang aktif menjadi aktif serta membantu siswa yang kurang mampu atau kurang cepat menerima pelajaran. Model pembelajaran CWPT juga mampu memperbaiki sikap siswa dalam proses pembelajaran karena pada sesi tutoring siswa dituntut untuk aktif baik berlaku sebagai tutor maupun tutee secara bergantian.

Kelas eksperimen yang menggunakan model pembelajaran classwide peer tutoring pada materi klasifikasi makhluk hidup pada pertemuan I dan pertemuan II siswa sangat berpartisipasi aktif dalam proses pembelajaran dimana pada sesi tutoring siswa bekerja sama dengan baik, menunjukan kemampuan dalam berkomunikasi serta memiliki rasa tanggung jawab untuk bekerja dalam kelompok sehingga meningkatkan interaksi sosial peserta didik dalam proses pembelajaran. Hal ini sejalan dengan pendapat Nobel (2005) menyatakan bahwa class-wide peer tutoring juga mampu memperbaiki self-concept, siswa di sekolah dan meningkatkan rasa nasionalisme.
Berbeda dengan kelas kontrol yang diberi perlakuan menggunakan model problem based learning, dalam model pembelajaran siswa dibagi kedalam kelompok besar sehingga dalam proses pembelajaran hanya sebagian siswa dalam kelompok yang aktif. Ketergantungan pada orang tertentu dalam kelompok masih berlaku pada kelas kontrol, dalam proses diskusi siswa juga kurang menunjukan keseriusan dalam mengerjakan tugas yang diberikan, tidak adanya rasa tanggung jawab siswa dalam kelompok karna kurangnya komunikasi dalam bekerja sama sehingga interaksi antara siswa pun berkurang. Maka dapat disimpulkan bahwa kelas esksperimen memiliki hasil observasi yang lebih baik daripada kelas kontrol.

Hasil ini dapat dilihat pada standar deviasi aktivitas belajar pada kelas ekperimen sebesar 3,00 dan kelas kontrol sebesar 000. Standar deviasi pada kelas ekperimen lebih besar dibandingkan dengan kelas kontrol. besarnya standar deviasi menunjukan bahwa aktivitas belajar siswa sangat jauh berbeda.

Tabel 2.Uji Hipotesis Aktivitas Belajar

\begin{tabular}{ccccc}
\hline Variabel & N & Mean & $\begin{array}{l}\text { Std Deviasi } \\
\text { kelas } \\
\text { Kontrol dan } \\
\text { Ekperimen }\end{array}$ & $\begin{array}{l}\text { Taraf } \\
\text { Signifikansi }\end{array}$ \\
\hline Aktivitas & 4 & 3,15 & 3,00 & 0,000 \\
Belajar & 4 & 2,00 & 000 & \\
\hline
\end{tabular}

Berdasarkan pengujian hipotesis pada tabel 4.8 nilai signifikansi yang diperoleh yaitu $0.000<0,05$ yang artinya terdapat hubungan signifikansi antara model pembelajaran class-wide peer tutoring yang dilihat dari aktivitas belajar siswa. Berdasarkan hal tersebut dapat disimpulkan bahwa model pembelajaran Class-Wide Peer 
Tutoring efektif terhadap aktivitas belajar siswa.

\section{b. Efektivitas Model Pembelajaran Class- Wide Peer Tutoring dilihat dari Hasil Belajar Kognitif.}

Data hasil belajar diperoleh dengan menggunakan soal pre-test dan post-test dengan jumlah soal 20 nomor. Siswa yang mengikuti pre-test dan post-test pada kelas eksperimen berjumlah 32 orang, dan kelas kontrol berjumlah 27 orang. Berdasarkan hasil pre-test pada kelas eksperimen diperoleh rentangan nilai 55-70 dengan nilai rata-rata 52,81; sedangkan pada post-test kelas ekperimen diperoleh rentangan nilai 70-90 dengan nilai rata-rata 80,62. Hasil pre-test pada kelas kontrol diperoleh rentangan nilai 35-70 dengan rata-rata nilai 49,44; sedangkan post-test pada kelas kontrol peroleh rentangan nilai 40-75 dengan nilai rata-rata 62,22.

Tabel 3.Nilai Rata-rata Hasil Belajar Kognitif Siswa

\begin{tabular}{cccc}
\hline \multicolumn{2}{c}{ Kelas eksperimen } & \multicolumn{2}{c}{ Kelas kontrol } \\
\hline Pretest & Posttest & Pretest & Posttest \\
\hline 52,81 & 80,62 & 49,44 & 62,22 \\
\hline
\end{tabular}

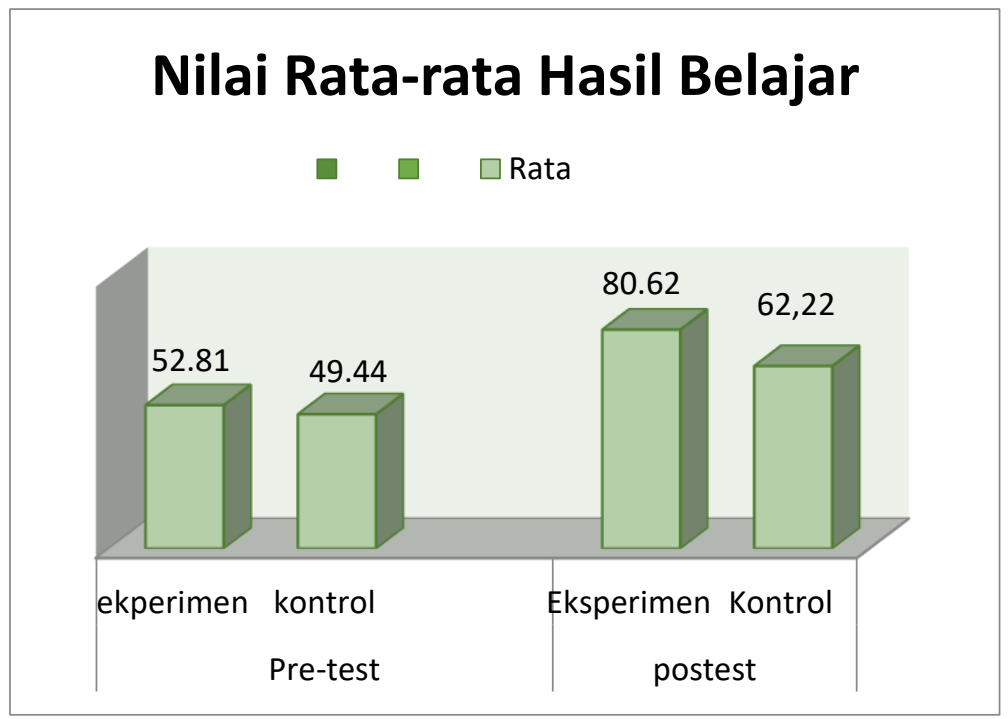

Gambar 2. Diagram Batang Hasil Belajar Kognitif

Berdasarkan gambar di atas, dapat dilihat bahwa terdapat perbedaan antara hasil belajar kelas kontrol dan kelas ekperimen. Pada pertemuan pertama, peneliti memberikan pre-test pada kelas ekperimen maupun kelas kontrol. pre-test ini bertujuan untuk mengetahui kemampuan awal peserta didik sebelum peneliti memberikan treatment. Data yang diperoleh dari hasil pre-test pada kelas ekperimen dengan nilai rata-rata sebesar 52,81 dan hasil pre-test pada kelas kontrol sebesar 
44,92, sedangkan data hasil post-tets pada kelas eksperimen diperoleh nilai rata-rata sebesar 80,62 dan nilai post-test pada kelas kontrol sebesar 62,22 seperti pada diagram yang terdapat diatas.

Pada kelas eksperimen dengan menggunakan model pembelajaran classwide peer tutoring pada pertemuan I dan II siswa berpartisipasi sangat aktif dimana dalam sesi turoring baik yang berperan sebagai tutor maupun tutee terlibat aktif dalam proses pembelajaran, siswa yang berperan sebagai tutor terlihat sangat antusias dalam memberikan pertanyaan kepada tutee begitu pun sebaliknya siswa yang berperan sebagai tutte terlihat semangat dalam menjawab pertanyaan yang diberikan. Siswa terlihat kompeten dalam menunjukan kemampuan inlektual satu sama lain namun ada beberapa siswa yang kurang tanggap dalam penyampaian materi. Greenwood, Meyer, \& Terry (2001) menjelaskan bahwa CWPT sangat membantu semua siswa dengan kemampuan yang berbeda dan mudah untuk diterapkan dalam pembelajaran. Model pembelajaran ini menuntut siswa berperan sebagai tutor dan tutee secara bergantian selama sesi tutoring, sehingga tutor maupun tutee menunjukkan peningkatan kemampuan penguasaan materi.
Berbeda dengan kelas kontrol yang diberi perlakuan menggunakan model problem based learning, siswa tidak memiliki niat atau tidak mempunyai kepercayaan bahwa masalah yang dipelajari sulit untuk dipecahkan, maka mereka akan merasa enggan untuk mencobanya. Sebagian siswa beranggapan bahwa tanpa pemahaman mengenai materi yang diperlukan untuk menyelesaikan masalah mengapa harus berusaha untuk memecahkan masalah yang sedang dipelajari, maka mereka akan belajar apa yang ingin mereka pelajari. Warsono dan Hariyanto (2012) menjelaskan bahwa tidak banyak guru yang mampu mengantarkan siswa kepada pemecahan masalah dan aktivitas siswa di luar sekolah sulit dipantau.

Hasil ini juga dapat dilihat pada standar deviasi posttest pada kelas ekperimen sebesar 7,378 sedangkan pada kelas kontrol sebesar 9,439. Standar deviasi pada kelas ekperimen lebih besar dari pada kelas kontrol. Hal ini disebabkan karna rentangan nilai Post-test pada kelas ekperimen berkisar 70-90. Rentangan nilai posttest kelas kontrol berkisar 40-75. Besarnya standar deviasi menunjukan bahwa tingkat pemahaman materi siswa pada kedua kelas sudah baik.

Tabel 4. Uji Hipotesis Kelas Eksperimen dan Kontrol

\begin{tabular}{ccccc}
\hline Variabel & N & Mean & $\begin{array}{c}\text { Std Deviasi } \\
\text { Kelas } \\
\text { ekperimen } \\
\text { dan } \\
\text { Kontrol }\end{array}$ & $\begin{array}{c}\text { Taraf } \\
\text { signifikan }\end{array}$ \\
\hline Hasil & 32 & 80,62 & 7,378 & 0.00 \\
Belajar & 27 & 62,22 & 9,434 & \\
\hline
\end{tabular}




Pengujian hipotesis dilakukan
menggunakan aplikasi SPSS 16 pada uji
Independent samples t- test dengan data
yang akan diujikan ialah data post test kelas
eksperimen dan kelas kontrol. Kriteria
dalam penerimaan dan penolakan hipotesis
adalah jika taraf signifikansinya < 0,05
maka hipotesis yang dirumuskan $\mathrm{H}_{1}$
(signifikan) dan $\mathrm{H}_{\mathrm{O}}$ ditolak (tidak
signifikan).

Pengujian hipotesis dilakukan menggunakan aplikasi SPSS 16 pada uji Independent samples $t$ - test dengan data yang akan diujikan ialah data post test kelas dalam penerimaan dan penolakan hipotesis adalah jika taraf signifikansinya < 0,05 (signifikan) dan yang dirumuskan $\mathrm{H}_{1}$ signifikan).

\begin{abstract}
Hasil analisis uji Independent samples $t$ - test nilai post-test kelas eksperimen dan kontrol diperoleh nilai signifikansi (2-tailed) adalah 0,00<0,05 yang artinya terdapat hubungan signifikansi antara model pembelajaran class-wide peer tutoring yang dilihat dari hasil belajar siswa. Hasil ini menunjukan bahwa model pembelajaran class wide peer tutoring efektif terhadap pembelajaran biologi pada kelas eksperimen.
\end{abstract}

belajar peserta didik pada kelas eksperimen sebesar 3,45 dan kelas kontrol sebesar 2,26 sedangkan pada hasil belajar kognitif pada kelas eksperimen setelah diberikan perlakuan lebih besar yaitu 80,62 dan kelas kontrol dengan nilai rata-rata 62,22.

\section{DAFTAR PUSTAKA}

Aprida, dkk. 2017. Belajar dan Pembelajaran. Fitrah: Jurnal Kajian Ilmu-Ilmu Kesehatan.

Arikunto, S. 2016. Dasar-dasar Evaluasi Pendidikan. Jakarta: Penerbit Bumi Aksara

Imaningtyas, S.A. 2016. Biologi untuk SMA/MA Kelas X Kurikulum 2013. Jakarta: Penerbit Erlangga

Irnaningtyas. 2016. Biologi untuk SMA/MA kelas X Kurikulum 2013. Jakarta: Penerbit Erlangga

Kemendikbud. 2016. Permendikbud Nomor 22 Tahun 2016 tentang standar pendidikan dan menengah . Jakarta: Kemendikbud 
Munawaroh, L., Pantiwati Y., dan Rifieq, A. 2015. Pengunaan Jurnal belajar dalam Pembelajaran Class Wide Peet Tutoring Terhadap Kemampuan Berpikir Kristis Siswa. Jurnal Pendidikan Biologi Indonesia. Vol. 1 (3): 263-273

Rohana, W.I. 2017. Pengaruh Metode Classwide Peer Tutoring Didukung Media Tiga Dimensi Terhadap Kemampuan Menjelaskan Pesawat Sederhana. Jurnal Simki-Pedagogia. Vol. 1 (4): $2-9$

Sani, A. R. 2015. Inovasi Pembelajaran. Jakarta: Bumi Aksara

Sugiyono. 2016. Metode Penelitian Pendidikan. Pendekatan Kuantitatif-kualitatif-R\&D. Bandung: Penerbit Alfabeta

Sudjana N. 2015. Penilaian Hasil Proses Belajar. Bandung: Remaja Rosdakarya.

Widoyoko, E. P. 2018. Penelitian Hasil Belajar di Sekolah. Yogyakarta: Pustaka Pelajar. 